J. Lake Sci. (湖泊科学), 2021, 33(6): 1805-1819

DOI 10. 18307/2021. 0616

(c) 2021 by Journal of Lake Sciences

\title{
西藏麦地卡湿地的浮游植物—1.优势种的时空生态位
}

\author{
潘成梅 $^{1 * *}$, 刘 洋 $^{1 * *}$, 安瑞志 ${ }^{1}$, 黄 香 $^{2}$, 巴 桑 ${ }^{1 * * *}$ \\ (1:西藏大学理学院青藏高原湿地与流域生态实验室,拉萨 850000) \\ (2:西藏大学理学院高原流域环境化学实验室,拉萨 850000)
}

\begin{abstract}
摘 要: 为了解青藏高原湿地浮游植物在时空不同维度上的分布特征, 本文选取西藏四大国际湿地之一的麦地卡湿地作 为研究地点, 于 2019 年 7 月和 10 月在麦地卡湿地主要水系——麦地藏布及其支流和湖泊, 设置了 14 个样点, 采集了 2 个水情期 (丰水期和枯水期) 浮游植物的水样共 252 个. 通过活体观察和固定染色方法鉴定浮游藻类物种, 使用直接计数 法统计浮游藻类的数量. 计算麦地卡湿地浮游植物优势种的优势度指数 $(Y)$ 、更替率 $(r)$ 、生态位宽度 $\left(B_{i}\right)$ 、生态位重叠 值 $\left(O_{i k}\right)$ 和生态响应速率 $(R)$, 运用生态位分化的方法, 对麦地卡湿地浮游植物优势种的生态位进行了不同时空维度的研 究. 结果表明: 本研究中鉴定出浮游植物优势种 $(Y>0.02)$ 共 8 种, 其中克洛脆杆藻 (Fragilaria crotomensis) 和窗格平板澡 (Tabellaria fenestrata) 是 2 个水情期的共有优势种. 生态位宽度值差异较大, 可分为三大生态位类群, 且优势度指数与生 态位宽度值呈极显著正相关. 总体上浮游植物优势物种的生态位重叠值高, 在时间、空间和时空三个维度上 $O_{i k}>0.6$ 的分 别占 $89.29 \% 、 60.71 \%$ 和 $28.57 \%$. 生态响应速率之和在时间维度上为负数,在空间和时空维度上为正数, 说明该湿地浮游 植物群落处于发展阶段. 冗余分析表明, 酸碱度、溶解氧、总氮和浊度是影响麦地卡湿地浮游植物优势种分布的重要因 素,浮游植物优势种在这些环境因子上存在明显的生态分化现象.
\end{abstract}

关键词: 西藏;麦地卡湿地;浮游植物;优势种;时空生态位; 元余分析

\section{Phytoplankton in the Mitika Wetland, Tibet, China: 1. Spatio-temporal niche of dominant species*}

Pan Chengmei ${ }^{1 * *}$, Liu Yang ${ }^{1 * *}$, An Ruizhi ${ }^{1}$, Huang Xiang ${ }^{2} \&$ Ba Sang ${ }^{1 * * *}$

(1: Laboratory of Wetland and Catchments Ecology in Tibetan Plateau, Faculty of Natural Sciences, Tibet University, Lhasa 850000 , P.R.China)

(2: Laboratory of Environmental Chemistry in Plateau Basin, Faculty of Natural Sciences, Tibet University, Lhasa 850000, P.R.China)

Abstract: In order to understand the distribution characteristics of phytoplankton at the spatial and temporal dimensions in wetlands in Qinghai-Tibet Plateau, Mitika Wetland, one of the four international wetlands in Tibet, was selected as the research area where 14 sampling points were set up along the main water system-Miti Tsangpo and its tributaries, and lakes in July and October 2019. A total of 252 water samples of phytoplankton were collected in two hydrological periods (wet season and dry season). The species of phytoplankton were identified by living observation and fixed staining method and counted by direct counting method. The dominance index $(Y)$, replacement rate $(r)$, niche width $\left(B_{i}\right)$, niche overlap value $\left(O_{i k}\right)$ and ecological response rate $(R)$ of the dominant phytoplankton species were calculated. The niche differentiation method was used to analyze the niche of dominant species of phytoplankton at different dimensions in time and space. According to the dominance index, 8 dominant species $(Y>0.02)$ of phytoplankton were identified among which Fragilaria crotomensis and Tabellaria fenestrata were the common dominant species in two periods, The niche width values of dominant species were quite different and can be divided into three niche groups, and the dominance index was posi-

* 2021-03-19 收稿; 2021-04-22 收修改稿.

科技部基础专项重点项目(22015FY111000)、国家自然科学基金项目(31660620)、2021 年中央支持地方高校发展 专项资金项目 (藏财预指 [2021] 1 号) 和西藏大学研究生 “高水平人才培养计划” 项目 (2019-GSP-S050) 联合资助.

** 并列第一作者; E-mail: panchengmei@ aliyun.com; E-mail: ly@ utibet.edu.cn.

*** 通信作者; E-mail: hbasang2003@ aliyun.com. 
tively correlated with the niche width. The niche overlap values of phytoplankton dominant species were high at the spatial, temporal and spatial-temporal dimensions with $O_{i k}>0.6$ accounting for $89.29 \%, 60.71 \%$ and $28.57 \%$, respectively. The sum of ecological response rates was negative at the temporal dimension and was positive at the spatial and the spatial-temporal dimension indicating that the phytoplankton community was at developing stage in the wetland. $\mathrm{RDA}$ analysis showed that, $\mathrm{pH}, \mathrm{DO}$, total nitrogen and turbidity were the important factors affecting the distribution of dominant phytoplankton species in the Mitika Wetland, and there was obvious ecological differentiation in the dominant species of phytoplankton at these environmental factors.

Keywords: Tibet; Mitika Wetland; phytoplankton; dominant species; spatio-temporal niche; RDA

浮游植物是湿地生态系统中具有重要作用的初级生产者, 其群落结构、优势种以及多样性的变化能直 接反映水环境的状况 ${ }^{[1-2]}$. 生态位 (ecological niche) 是指一个生态系统中, 某一种群在时间、空间上所占据的 位置及其与相关种群的功能关系与作用,是有机体和环境因素的综合 ${ }^{[3-4]}$. 生态位理论揭示了物种在时间、 空间等方面的种间竞争与共存关系, 是近代生态学的重要研究领域之一 ${ }^{[5-6]}$. 种群在时间维度上的分布比例 反映了随着季节变化和资源多维的依存关系, 种群在空间位置的不同比例亦反映了空间多维资源的位置异 质关系 ${ }^{[7-8]}$. 由于物种的存在离不开空间和时间, 二者缺一不可, 因此时空二维生态位能比较准确地提示物 种间竞争共存机制 ${ }^{[9]}$. 物种生态位分化的信息有助于理解同域分布物种的生存状况, 为生物多样性管理与 保护提供建议 ${ }^{[10]}$. 目前, 关于时空生态位的研究常见于鱼类、虾类、头足类和蛾类等生物 ${ }^{[1-1-14]}$, 浮游植物生 态位的研究仅限于空间生态位 ${ }^{[15-17]}$, 有关浮游植物时空生态位研究报道较少.

青藏高原湿地分布广泛, 面积达 $131894.18 \mathrm{hm}^{2}$, 其中西藏自治区境内湿地总面积达 $65290.29 \mathrm{hm}^{2}$, 且以天 然湿地为主, 约占自治区土地总面积的 $5.35 \%{ }^{[18]}$. 再者西藏是世界上湿地发育最丰富、湖泊面积最大、河流发 育最多的地区, 境内湿地生态系统类型多样, 因而备受国内外研究生物起源、进化、区系和迁徙的学者广泛关 注 ${ }^{[19-20]}$. 麦地卡湿地、玛旁雍错湿地、色林措湿地和扎日南木错湿地是西藏四大国际湿地, 作为西藏最早被列 人国际湿地的麦地卡湿地, 位于西藏那曲地区, 面积 $43496 \mathrm{hm}^{2}$, 平均海拔 $4900 \mathrm{~m}$, 属于高原湖泊沼泽草甸湿 地,2016 年被国务院批准为国家级自然保护区. 该湿地对于本地水土保持、防止季节性洪水泛滥、阻截上游沉 积物并形成生产力很高的草甸、沼泽类型湿地具有重要作用, 也是当地牧民和牲畜的重要生活水源. 至今有关 麦地卡湿地的生物学研究主要集中在种子植物、原生动物等方面 ${ }^{[21-22]}$, 浮游植物的研究鲜有报道.

本研究以麦地卡湿地国家级自然保护区自然水域为主体,通过时空二维的生态位测度方法对麦地卡湿 地的浮游植物优势种展开分析, 定性、定量地评估浮游植物优势种的生态位, 揭示时空不同维度浮游植物优 势种生态位的资源利用状况及生态适应性等相关信息, 以期为进一步研究麦地卡湿地浮游植物群落的稳定 性和时空分布格局提供依据. 为该湿地浮游植物的种群特征、生存状况、资源保护与利用提供基础资料, 并 为浮游植物优势种的时空生态位相关研究提供参考.

\section{1 研究区概况}

麦地卡湿地类型齐全, 功能完善, 是高寒湖泊、河流与沼泽湿地生态系统中的典型代表, 是研究高原湖 泊湿地生态、河流湿地生态以及沼泽湿地生态系统的理想场所 ${ }^{[19]}$. 麦地卡湿地 $\left(30^{\circ} 51^{\prime} 04^{\prime \prime} \sim 31^{\circ} 09^{\prime} 44^{\prime \prime} \mathrm{N}\right.$, $92^{\circ} 45^{\prime} 55^{\prime \prime} \sim 93^{\circ} 19^{\prime} 25^{\prime \prime} \mathrm{E}$ ) 属于国家级自然保护区, 位于西藏自治区那曲市嘉黎县北部麦地卡乡境内, 平均海 拔为 $4900 \mathrm{~m}$, 占地面积为 $88052.37 \mathrm{hm}^{2[18]}$. 该保护区内气候属于高原亚寒带半湿润气候, 年平均气温 $0.9^{\circ} \mathrm{C}$, 年日照时数为 $2211.8 \mathrm{~h}$, 年均降水量 $694 \mathrm{~mm}$, 年蒸发量 $1400 \mathrm{~mm}$, 年无霜期 $78 \mathrm{~d}$. 丰水期主要集中在 6-9 月,降雨量占全年的 $76 \%$,枯水期在 $10-5$ 月,仅占 $24 \%$,干湿分明 ${ }^{[23]}$.

\section{2 研究方法}

\section{1 样点设置}

根据麦地卡湿地水系分布, 在三大核心区设置代表其生态环境特征的 14 个样点 (图 1), 湿地内水系分 布呈树枝状, 为外流水系, 主干流是麦地藏布, 发源于麦地卡湿地保护区东北部核心区的彭错. 沼泽湿地主 要分布在各大小湖泊的湖滨及麦地藏布两岸. 湖泊湿地包括错热错 (M2)、松董错 (M4)、错董错 (M6)、瓦瑞 错 (M7)、东德错 (M10) 和乌穷错 (M13), 除瓦瑞错 (封闭湖) 外, 这些湖泊最终汇集于麦地藏布, 河流湿地包 
括秋朗曲 (M1)、玛荣曲 (M3)、松董曲 (M5)、热达曲 (M8)、麦地藏布上游 (M9)、乌铅曲 (M12) 和麦地藏布下 游 (M14), 是麦地藏布的主干流及支流, 沼泽湿地为错查错 (M11). 分别于 2019 年 7 月 (丰水期) 和 10 月 (枯水期) 进行水环境因子与浮游植物样品采集.

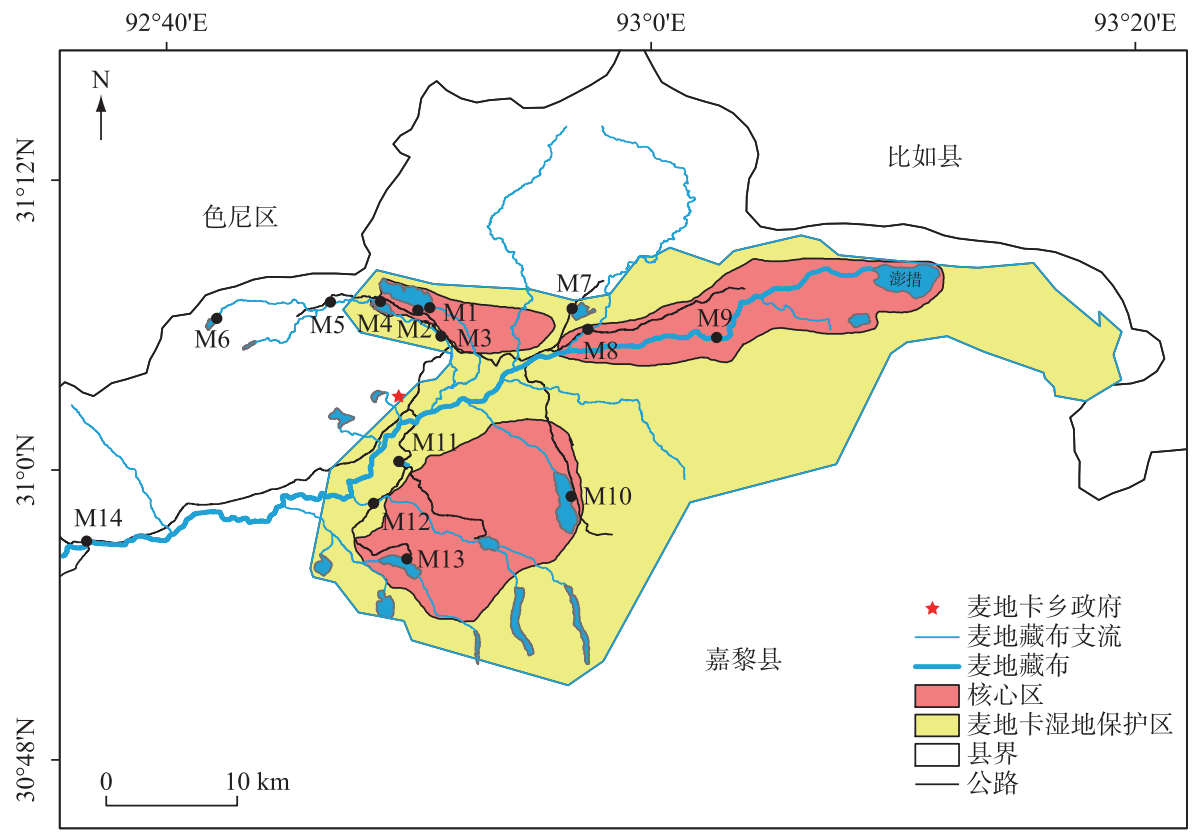

图 1 麦地卡湿地样点位分布

Fig.1 Distribution of sampling sites in Mitika Wetland

\section{2 水样采集、处理及鉴定方法}

浮游植物的调查方法根据《淡水浮游生物研究方法》 ${ }^{[24]}$ 中规定的方法进行采集和鉴定. 定性样品用 $25^{\#}$ (孔径 $64 \mu \mathrm{m}$ ) 浮游生物网在水下 $0 \sim 0.5 \mathrm{~m}$ 处作“ $\infty$ ” 型过滤, 将样品浓缩至 $500 \mathrm{~mL}$ 装人标本瓶, 在室内利用 LEICA DM500 研究型光学显微镜, 采用活体镜检鉴定物种. 定量样品在 $0 \sim 0.5 \mathrm{~m}$ 深度处采集 $1 \mathrm{~L}$ 混合水样, 随后立即用鲁哥氏试剂固定, 样品带回实验室沉淀 $48 \mathrm{~h}$ 后浓缩至 $50 \mathrm{~mL}$, 移取 $0.1 \mathrm{~mL}$ 浓缩匀液至 $0.1 \mathrm{~mL}$ 计 数框, 在 $10 \times 40$ 倍显微镜下全片计数, 每个样品计数 $2 \sim 3$ 次. 浮游植物的鉴定参考经典文献 ${ }^{[25-28]}$.

现场使用 HI98195 高精度便携式多参数综合水质测试仪 (HANNA, 意大利) 测定水体酸碱度 $(\mathrm{pH})$ 、电导率 (EC)、总溶解盐 ( TDS)、盐度 (Salt) 及水温 (WT), 使用 HI98193 微电脑溶解氧测定仪 (HANNA, 意大利) 测得溶 解氧 (DO), 使用 HI98703 微电脑多量程浊度测定仪 (HANNA, 意大利) 测得浊度 (TUR) 等, 并分别进行 3 个平 行检测. 严格按照《地表水环境的质量标准》GB 3838-2002 对水样进行采集、保存与运输,送有检测资质公司 对总磷 $(\mathrm{TP})$ 、总氮 $(\mathrm{TN})$ 、氨氮 $\left(\mathrm{NH}_{3}-\mathrm{N}\right)$ 、硝酸盐氮 $\left(\mathrm{NO}_{3}^{-}-\mathrm{N}\right)$ 和重铬酸盐指数 $\left(\mathrm{COD}_{\mathrm{Cr}}\right)$ 等指标进行测定.

\section{3 数据处理与分析}

2.3.1 优势种 依据 McNaughton 优势度指数 $(Y)^{[29-30]}$ 确定优势种, 计算公式如下:

$$
Y=F_{i} \cdot n_{i} / n
$$

式中, $F_{i}$ 为第 $i$ 种出现的频率, $n$ 为同一样点中的个体总数, $n_{i}$ 为第 $i$ 种的个体数; $Y>0.02$ 则为优势种, $Y>0.1$ 为绝对优势种.

2.3.2 优势种更替率 根据优势种更替率 $(r)^{[31-32]}$ 分析优势种的季节更替, 其计算公式如下:

$$
r=(a+b-2 c) /(a+b-c) \times 100 \%
$$

式中, $a 、 b$ 为相邻两季优势种数, $c$ 为相邻两季共同优势种的种类数.

2.3.3 生态位宽度 生态位宽度 $\left(B_{i}\right)$ 采用 Colwell 等加权修正的 Levins 指数 ${ }^{[33]}$, 计算公式如下: 


$$
B_{i}=1 / r \sum_{j=1}^{r} P_{i j}^{2}
$$

式中, $B_{i}$ 为物种的生态位宽度, $P_{i j}$ 为物种 $i$ 在第 $j$ 个样点的个体数占该种所有个体数的比例, $P_{i}=N_{i j} / N_{i}, i$ 表 示物种, $j$ 为资源 (季节或样点), $N_{i j}$ 为种群 $i$ 在季节或样点 $j$ 的数量, $N_{i}$ 为种群 $i$ 的总数量, $r$ 为采样点数.

2.3.4 生态位重叠与生态响应速率 生态位重叠指数 $\left(O_{i k}\right)$ 选用 Pinaka 指数 ${ }^{[34]}$, 计算公式如下:

$$
\begin{gathered}
O_{i k}=\frac{\sum_{j=1}^{N}\left(P_{i j} \cdot P_{k j}\right)}{\sqrt{\sum_{j=1}^{N} P_{i j}^{2} \cdot \sum_{j=1}^{N} P_{k j}^{2}}} \\
\Delta O_{i k}=\sum_{k=1} O_{i k}-\sum_{i=1} O_{i k} \\
R=B_{i} / \Delta O_{i k}
\end{gathered}
$$

式中, $O_{i k}$ 为物种 $i$ 与物种 $k$ 的生态位重叠指数, 其值越大表示生态位重叠程度最高, 其取值范围为 $0 \sim 1 ; P_{i j}$ 为 物种 $i$ 利用资源状态 $j$ (季节或样点) 的个体数占该种个体总数的比例; $P_{k j}$ 为物种 $k$ 利用资源状态 $j$ (季节或 站位) 的个体数占该种个体总数的比例. $O_{i k}>0.3$ 时, 认为种对之间生态位的重叠有意义, $O_{i k}>0.6$ 时, 认为种 对之间有显著的生态位重叠 ${ }^{[35]}$. 当 $i=k$ 时, $\Delta O_{i k}>0$, 说明该种处于发展期, $\Delta O_{i k}<0$, 该种处于衰退期, 当 $\Delta O_{i k}=0$, 该种是中性的. $R$ 表示生态响应速率.

2.3.5 时空生态位 根据 $\operatorname{Cody}^{\left[{ }^{[36]}\right]}$ 和 May ${ }^{[37]}$ 提出用 2 个原则来估计在多维资源轴上的生态位特征值, 麦地卡 湿地浮游植物优势种的时间一空间二维生态位宽度和重叠由浮游植物时间和空间生态位特征值的乘积来 表示:

时空生态位宽度值 $=$ 时间生态位宽度 $\times$ 空间生态位宽度

时空生态位重叠值 $=$ 时间生态位重叠 $\times$ 空间生态位重叠

式中, 时间、空间生态位宽度为 Levins 指数计算结果, 时间、空间生态位重叠为 Pianka 指数计算结果.

2.3.6 数据统计和处理分析 采用 ArcGIS 10.0 软件绘制地图, 利用 Excel 2016 软件计算浮游植物优势种丰 度、生态位宽度和生态位重叠值, 应用 R 3.6.2 软件 ggtree 和 ggplot2 包对时间、空间和时空生态位宽度进行 聚类分析, 使用 Canoco 5.0 对浮游植物优势种与相关环境因子的关系进行尣余分析及排序图绘制.

\section{3 结果与分析}

\section{1 优势种}

在本研究中, 麦地卡湿地丰水期共鉴定浮游植物 305 种, 隶属于 7 门 9 纲 20 目 34 科 88 属; 枯水期共鉴 定浮游植物 288 种, 隶属于 6 门 8 纲 20 目 28 科 63 属. 表 1 是麦地卡湿地 2 个水情期优势种的分布名录, 丰 水期优势种较多,为 7 种,枯水期优势种较少,仅有 3 种.

\begin{tabular}{|c|c|c|c|c|c|c|c|c|c|c|c|c|c|c|c|}
\hline 水情期 & 优势种 & M1 & M2 & M3 & M4 & M5 & M6 & M7 & M8 & M9 & M10 & M11 & M12 & M13 & M14 \\
\hline \multirow[t]{7}{*}{ 丰水期 } & 偏肿桥弯藻 Cymbella ventricosa & & & $* *$ & $* *$ & $*$ & $*$ & $*$ & $*$ & $*$ & & $*$ & $*$ & $*$ & $*$ \\
\hline & 钝脆杆藻 Fragilaria capucina & $* *$ & $*$ & $*$ & $* *$ & $*$ & $*$ & $*$ & $*$ & $*$ & $*$ & $*$ & $*$ & $*$ & $*$ \\
\hline & 克洛脆杆藻 Fragilaria crotomensis & $* *$ & $* *$ & $* *$ & $* *$ & $* *$ & $*$ & $* * *$ & $* *$ & $* *$ & $* *$ & $* *$ & $* *$ & $* *$ & $* *$ \\
\hline & 纱缩异极藻 Gomphonema constrictum & $* *$ & & $* *$ & & $* *$ & $* *$ & $*$ & $* *$ & $*$ & & $*$ & $* *$ & $*$ & $*$ \\
\hline & 棒形鼓藻 Gonatozygon monotaenium & $*$ & $*$ & $* *$ & $* *$ & $* *$ & $*$ & $*$ & $* *$ & $* *$ & $*$ & $*$ & $* *$ & $*$ & $* *$ \\
\hline & 尖针杆藻 Synedra acus & $* *$ & $*$ & $* *$ & $*$ & $* *$ & $*$ & $*$ & $*$ & $*$ & $*$ & $*$ & $*$ & $* *$ & $* *$ \\
\hline & 窗格平板藻 Tabellaria fenestrata & $*$ & $*$ & $* *$ & $*$ & $*$ & $*$ & $*$ & & $* *$ & $*$ & & $*$ & $*$ & $* *$ \\
\hline \multirow[t]{3}{*}{ 枯水期 } & 克洛脆杆藻 Fragilaria crotomensis & $* *$ & $* *$ & $* *$ & $* *$ & $* *$ & $* *$ & $* *$ & $* *$ & $* *$ & $* *$ & $* *$ & $* *$ & $* *$ & $* *$ \\
\hline & 水绵藻一种 Spirogyra sp. & $* *$ & & $*$ & $* *$ & & $*$ & $*$ & $* *$ & $* *$ & $*$ & $*$ & & $*$ & \\
\hline & 窗格平板藻 Tabellaria fenestrata & $*$ & $* *$ & $*$ & $* *$ & $* *$ & $*$ & $* *$ & $*$ & $*$ & $*$ & $*$ & & $*$ & $*$ \\
\hline
\end{tabular}

表 1 麦地卡湿地浮游植物优势种名录

Tab.1 List of dominant phytoplankton species in Mitika Wetland

*、**、*** 分别表示数量极差为 $10 、 100 、 1000($ cells $/ \mathrm{L})$. 
根据优势度的计算结果 (表 2), 硅藻门有 6 种, 绿藻门有 2 种, 显示麦地卡湿地水体为贫营养型, 克洛脆 杆藻 (Fragilaria crotomensis) 和窗格平板藻 (Tabellaria fenestrata) 是 2 个水情期共有优势种, 优势种出现频 率、丰度和优势度在不同水情期均有差异. 克洛脆杆藻的丰度和优势度在 2 个水情期都最高, 为绝对优势种 $(Y>0.1)$. 根据优势种更替率计算公式, 2 个水情期优势种的更替率为 $75 \%$, 表明麦地卡湿地浮游植物的优 势种组成存在明显的季节性差异.

表 2 麦地卡湿地不同水情期浮游植物优势种出现频率 $\left(f_{i}\right)$ 、丰度 $\left(A, \times 10^{4}\right.$ cells $\left./ \mathrm{L}\right)$ 及优势度 $(Y)$

Tab.2 Frequency $\left(f_{i}\right)$, abundance $\left(A, \times 10^{4}\right.$ cells $\left./ \mathrm{L}\right)$ and dominance $(Y)$ of dominant phytoplankton species in different hydrological periods in Mitika Wetland

\begin{tabular}{|c|c|c|c|c|c|c|c|}
\hline \multirow{2}{*}{ 门 } & \multirow{2}{*}{ 优势种 } & \multicolumn{3}{|c|}{ 丰水期 } & \multicolumn{3}{|c|}{ 枯水期 } \\
\hline & & $f_{i}$ & $A$ & $Y$ & $f_{i}$ & $A$ & $Y$ \\
\hline 硅藻门 & 偏肿桥弯藻 & $78.57 \%$ & 9.102 & 0.020 & $64.29 \%$ & 5.426 & $0.005^{*}$ \\
\hline \multirow[t]{5}{*}{ Bacillariophyta } & 钝脆杆藻 & $100 \%$ & 7.375 & 0.021 & $85.71 \%$ & 13.958 & $0.016^{*}$ \\
\hline & 克洛脆杆藻 & $100 \%$ & 47.674 & 0.134 & $100 \%$ & 83.880 & 0.112 \\
\hline & 缢缩异极藻 & $78.57 \%$ & 15.484 & 0.034 & $85.71 \%$ & 7.399 & 0.008 * \\
\hline & 尖针杆藻 & $100 \%$ & 13.994 & 0.039 & $78.57 \%$ & 6.997 & 0.007 * \\
\hline & 窗格平板藻 & $85.71 \%$ & 9.657 & 0.023 & $92.86 \%$ & 27.605 & 0.034 \\
\hline 绿藻门 & 棒形鼓藻 & $100 \%$ & 21.608 & 0.061 & $78.57 \%$ & 9.538 & 0.010 * \\
\hline Chlorophyta & 水绵藻一种 & $42.86 \%$ & 3.179 & 0.004 * & $71.43 \%$ & 22.037 & 0.021 \\
\hline
\end{tabular}

“*”表示该物种在该季节不是优势种.

\section{2 生态位宽度}

麦地卡浮游植物优势种生态位宽度 (表 3) 显示, 在时间维度上, 浮游植物优势种的生态位 宽度的变化幅度较小, 范围为 $0.266 \sim 0.390$, 平均 值为 0.294 , 最大值为水绵藻一种, 其次为窗格平 板藻, 最小值为偏肿桥弯藻; 在空间维度上, 浮游 植物优势种的生态位宽度的变化幅度较大, 变化 范围为 $0.358 \sim 0.779$, 平均值为 0.526 , 最大值为 克洛脆杆藻, 其次为棒形鼓藻, 最小值为偏肿桥 弯藻; 在时空维度上, 生态位宽度变化范围为 $0.095 \sim 0.210$, 平均值为 0.154 , 最大值为克洛脆杆 藻, 其次为水绵藻一种, 最小值为偏肿桥弯藻.

根据浮游植物优势种在 3 个生态位指标的 聚类分析 (图 2), 麦地卡湿地浮游植物优势种可 分为三大类:第一类是生态位宽度值较高的种
表 3 麦地卡湿地浮游植物优势种时间、 空间以及时空二维生态位宽度对比

Tab.3 Spatio, temporal and spatio-temporal two-dimensional niche width of dominant phytoplankton species in Mitika Wetland

\begin{tabular}{ccccc}
\hline 物种编号 & 优势种 & \multicolumn{4}{c}{ 时间生态位 空间生态位 时空生态位 } \\
\hline S1 & 偏肿桥弯藻 & 0.266 & 0.358 & 0.095 \\
S2 & 钝脆杆藻 & 0.274 & 0.414 & 0.113 \\
S3 & 克洛脆杆藻 & 0.269 & 0.779 & 0.210 \\
S4 & 缢缩异极藻 & 0.281 & 0.559 & 0.157 \\
S5 & 棒形鼓藻 & 0.288 & 0.569 & 0.164 \\
S6 & 水绵藻一种 & 0.390 & 0.465 & 0.181 \\
S7 & 尖针杆藻 & 0.278 & 0.521 & 0.145 \\
S8 & 窗格平板藻 & 0.308 & 0.541 & 0.167 \\
\hline
\end{tabular}
类, 这类物种为广生态位类群, 对环境适应能力强, 利用资源能力高; 第二类是生态位宽度值较低的中生态 位类群, 对资源的利用及对环境的适应能力较弱; 第三类为生态位宽度值最小的窄生态位类群, 对生境要求 较高, 对水体环境条件变化敏感. 在时间维度上,广生态位类群有水绵藻一种, 中生态位类群有窗格平板藻, 窄生态位类群有尖针杆藻、䍀缩异极藻、钝脆杆藻、棒形鼓藻、克洛脆杆藻和偏肿桥弯藻; 在空间维度上, 广 生态位类群有克洛脆杆藻, 中生态位类群有窗格平板藻、尖针杆藻、棒形鼓藻和䍀缩异极藻, 窄生态位类群 有水绵藻一种、钝脆杆藻和偏肿桥弯藻; 在时空维度上, 广生态位类群有克洛脆杆藻和水绵藻一种, 中生态 位类群有窗格平板藻、棒形鼓藻、䍀缩异极藻和尖针杆藻, 窄生态位类群有针脆杆藻和偏肿桥弯藻.

\section{3 生态位重叠}

在时间维度上, 钝脆杆藻和克洛脆杆藻、缢缩异极藻和棒形鼓藻的生态位重叠值最高 $(>0.999)$, 棒形鼓 

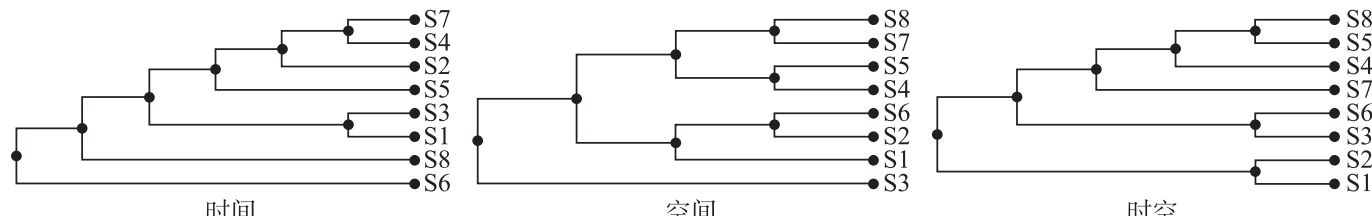

图 2 麦地卡湿地浮游植物优势种的生态位宽度聚类分析(物种种类编号同表 3 ,下同)

Fig. 2 Cluster analysis of niche width of dominant phytoplankton species in Mitika Wetland

藻和尖针杆藻的重叠值为 0.999 , 而棒形杆藻和水绵藻一种的时间生态位重叠值最小 $(0.530)$. 在 28 种对优 势种中, 时间生态位重叠值在 0.6 及以上的有 25 种对, 占总种对数的 $89.29 \%$; 有 3 种对重叠度较低 ( $0.3 \sim$ 0.6 ), 占总种对数的 $10.71 \%$; 表明该研究湿地浮游植物优势种时间维度的生态位重叠以高等级为主(表 4).

表 4 麦地卡湿地浮游植物优势种时间生态位重叠值*

Tab.4 Time niche overlap value of dominant phytoplankton species in Mitika Wetland

\begin{tabular}{ccccccccc}
\hline 物种编号 & $\mathrm{S} 1$ & $\mathrm{~S} 2$ & $\mathrm{~S} 3$ & $\mathrm{~S} 4$ & $\mathrm{~S} 5$ & $\mathrm{~S} 6$ & $\mathrm{~S} 7$ & $\mathrm{~S} 8$ \\
\hline $\mathrm{S} 1$ & 1 & & & & & & & \\
$\mathrm{~S} 2$ & $\mathbf{0 . 8 5 4}$ & 1 & & & & & & \\
$\mathrm{~S} 3$ & $\mathbf{0 . 8 7 0}$ & $>\mathbf{0 . 9 9 9}$ & 1 & & & & & \\
$\mathrm{~S} 4$ & $\mathbf{0 . 9 9 6}$ & $\mathbf{0 . 8 0 3}$ & $\mathbf{0 . 8 2 1}$ & 1 & & & & \\
$\mathrm{~S} 5$ & $\mathbf{0 . 9 9 3}$ & $\mathbf{0 . 7 8 4}$ & $\mathbf{0 . 8 0 3}$ & $>\mathbf{0 . 9 9 9}$ & 1 & & & \\
$\mathrm{~S} 6$ & $\mathbf{0 . 6 2 9}$ & $\mathbf{0 . 9 4 2}$ & $\mathbf{0 . 9 3 1}$ & 0.556 & 0.530 & 1 & & \\
$\mathrm{~S} 7$ & $\mathbf{0 . 9 9 7}$ & $\mathbf{0 . 8 1 3}$ & $\mathbf{0 . 8 3 1}$ & $>\mathbf{0 . 9 9 9}$ & $\mathbf{0 . 9 9 9}$ & 0.570 & 1 & \\
$\mathrm{~S} 8$ & $\mathbf{0 . 7 6 7}$ & $\mathbf{0 . 9 8 9}$ & $\mathbf{0 . 9 8 4}$ & $\mathbf{0 . 7 0 5}$ & $\mathbf{0 . 6 8 3}$ & $\mathbf{0 . 9 8 1}$ & $\mathbf{0 . 7 1 7}$ & 1 \\
\hline
\end{tabular}

* 加粗数字表示生态位重叠值大于 0.6 , 代表种间显著重叠, 下同.

在空间维度上, 缢缩异极藻和尖针杆藻的生态位重叠值最高 (0.804), 偏肿桥弯藻和棒形鼓藻的生态位 重叠较高 (0.788), 而水绵藻一种和尖针杆藻的生态位重叠值最小 (0.289). 在 28 种对优势种中, 空间生态 位重叠值在 0.6 及以上的有 17 种对, 占总种对数的 $60.71 \%$; 有 10 种对重叠值较低 $(0.3 \sim 0.6)$, 占总种对数 的 $35.71 \%$; 剩余 1 种对生态位重叠值在 0.3 以下, 属于重叠度低等级, 占总种对数的 $3.57 \%$, 表明该研究湿地 浮游植物优势种空间维度的生态位重叠以高、中两个等级为主 (表 5).

在时空维度上, 缢缩异极藻和尖针杆藻的生态位重叠值最高 (0.804), 水绵藻和尖针杆藻的生态位重叠值 最小 ( 0.165$)$. 在 28 种对优势种中, 时空生态位重叠值在 0.6 及以上的有 8 种对, 占总种对数的 $28.57 \%$; 有 17 种对重叠度较低 $(0.3 \sim 0.6)$, 占总种对数的 $60.71 \%$; 剩余 3 种对生态位重叠值均在 0.3 以下, 属于重叠度低等 级, 占总种对数的 $10.71 \%$, 表明该研究湿地浮游植物优势种时空二维的生态位重叠以中等等级为主(表 6).

表 5 麦地卡湿地浮游植物优势种空间生态位重叠值

Tab.5 Spatial niche overlap value of dominant phytoplankton species in Mitika Wetland

\begin{tabular}{ccccccccc}
\hline 物种编号 & $\mathrm{S} 1$ & $\mathrm{~S} 2$ & $\mathrm{~S} 3$ & $\mathrm{~S} 4$ & $\mathrm{~S} 5$ & $\mathrm{~S} 6$ & $\mathrm{~S} 7$ & $\mathrm{~S} 8$ \\
\hline $\mathrm{S} 1$ & 1 & & & & & & & \\
$\mathrm{~S} 2$ & 0.577 & 1 & & & & & \\
$\mathrm{~S} 3$ & 0.595 & 0.570 & 1 & & & & \\
$\mathrm{~S} 4$ & $\mathbf{0 . 6 3 1}$ & $\mathbf{0 . 6 6 2}$ & $\mathbf{0 . 6 8 8}$ & 1 & & & & \\
$\mathrm{~S} 5$ & $\mathbf{0 . 7 8 8}$ & $\mathbf{0 . 7 5 6}$ & $\mathbf{0 . 6 4 8}$ & $\mathbf{0 . 7 2 2}$ & 1 & & & \\
$\mathrm{~S} 6$ & 0.487 & 0.376 & 0.582 & 0.415 & 0.554 & 1 & & \\
$\mathrm{~S} 7$ & $\mathbf{0 . 6 4 6}$ & $\mathbf{0 . 6 9 0}$ & $\mathbf{0 . 7 0 7}$ & $\mathbf{0 . 8 0 4}$ & $\mathbf{0 . 6 8 6}$ & 0.289 & $\mathbf{0 . 6 3 5}$ & 1 \\
$\mathrm{~S} 8$ & 0.583 & $\mathbf{0 . 7 7 6}$ & $\mathbf{0 . 7 7 2}$ & $\mathbf{0 . 6 3 2}$ & $\mathbf{0 . 6 9 7}$ & 0.364 & $\mathbf{0 . 7 5 9}$ & \\
\hline
\end{tabular}


表 6 麦地卡湿地浮游植物优势种时空二维生态位重叠值

Tab.6 Spatio-temporal two-dimensional niche overlap value of dominant phytoplankton species in Mitika Wetland

\begin{tabular}{ccccccccc}
\hline 物种编号 & $\mathrm{S} 1$ & $\mathrm{~S} 2$ & $\mathrm{~S} 3$ & $\mathrm{~S} 4$ & $\mathrm{~S} 5$ & $\mathrm{~S} 6$ & $\mathrm{~S} 7$ & $\mathrm{~S} 8$ \\
\hline $\mathrm{S} 1$ & 1 & & & & & & & \\
$\mathrm{~S} 2$ & 0.493 & 1 & & & & & & \\
$\mathrm{~S} 3$ & 0.518 & 0.569 & 1 & & & & & \\
S4 & $\mathbf{0 . 6 2 8}$ & 0.531 & 0.564 & 1 & & & & \\
S5 & $\mathbf{0 . 7 8 2}$ & 0.593 & 0.520 & $\mathbf{0 . 7 2 2}$ & 1 & & & \\
S6 & 0.307 & 0.354 & 0.542 & 0.230 & 0.294 & 1 & & \\
S7 & $\mathbf{0 . 6 4 4}$ & 0.561 & 0.588 & $\mathbf{0 . 8 0 4}$ & $\mathbf{0 . 6 8 5}$ & 0.165 & 1 & \\
S8 & 0.447 & $\mathbf{0 . 7 6 8}$ & $\mathbf{0 . 7 6 0}$ & 0.446 & 0.477 & 0.358 & 0.544 & 1 \\
\hline
\end{tabular}

\section{4 生态响应速率}

麦地卡湿地时空不同维度浮游植物群落优势种的相对资源占有量 $\left(\Delta O_{i k}\right)$ 和生态响应速率 $(R)$ 结果如 表 7 所示. 可以看出, 无论在时间、空间还是时空维度上,水绵藻一种的 $\Delta O_{i k}$ 变化幅度 (即绝对值) 最大; 时间 维度上,水绵藻一种有最大的负 $\Delta O_{i k}$, 表明该种衰退空间最大, 缢缩异极藻、棒形鼓藻和窗格平板藻同属于 衰退型, 生长空间同呈缩小趋势; 偏肿桥弯藻、钝脆杆藻、克洛脆杆藻和尖针杆藻同处于发展型, 其中克洛脆 杆藻有最大的正 $\Delta O_{i k}$, 表明该种发展空间最大, 与其他优势种在资源利用上竞争激烈, 且占据竞争优势. 空 间维度上,偏肿桥弯藻和水绵藻一种属于衰退型, 其他各优势种处于发展型; 棒形鼓藻有最大的发展空间, 大于其他优势种, 窗格平板藻的发展空间略小于棒形鼓藻, 钝脆杆藻的发展空间最小. 时空维度上, 除了水 绵藻一种, 其他优势种都处于发展型, 棒形鼓藻有最大的正 $\Delta O_{i k}$, 其次是克洛脆杆藻的发展空间, 最小的发 展空间是窗格平板藻.

表 7 麦地卡湿地浮游植物优势种相对占用资源量 $\left(\Delta O_{i k}\right)$ 及生态响应速率 $(R)$

Tab.7 Relative occupied resources $\left(\Delta O_{i k}\right)$ and ecological response rate $(R)$ of dominant phytoplankton species in Mitika Wetland

\begin{tabular}{|c|c|c|c|c|c|c|}
\hline \multirow{2}{*}{ 物种编号 } & \multicolumn{2}{|c|}{ 时间 } & \multicolumn{2}{|c|}{ 空间 } & \multicolumn{2}{|c|}{ 时空 } \\
\hline & $\Delta O_{i k}$ & $R$ & $\Delta O_{i k}$ & $R$ & $\Delta O_{i k}$ & $R$ \\
\hline S1 & 1.752 & 0.152 & -0.454 & -0.788 & 0.764 & 0.125 \\
\hline S2 & 2.383 & 0.115 & 0.340 & 1.218 & 1.168 & 0.097 \\
\hline S3 & 2.814 & 0.096 & 1.584 & 0.492 & 2.702 & 0.078 \\
\hline S4 & -0.062 & -4.525 & 1.516 & 0.368 & 1.620 & 0.097 \\
\hline S5 & -0.758 & -0.379 & 3.890 & 0.146 & 2.789 & 0.059 \\
\hline S6 & -5.976 & -0.065 & -10.373 & -0.045 & -11.790 & -0.015 \\
\hline S7 & 0.328 & 0.846 & 1.733 & 0.301 & 2.142 & 0.068 \\
\hline S8 & -0.481 & -0.640 & 1.763 & 0.307 & 0.605 & 0.275 \\
\hline
\end{tabular}

基于生态响应速率 $(R)$ 可进一步确定不同维度优势种对生境条件的生态响应状况. 时间维度上, 尖针 杆藻的发展趋势最为强烈 $(R=0.846)$, 偏肿桥弯藻的发展趋势较为强烈 $(R=0.152)$, 钝脆杆藻的发展趋势较 弱 $(R=0.115)$, 克洛脆杆藻的发展趋势最弱 $(R=0.096)$; 䍀缩异极藻的衰退趋势最为强烈 $(R=-4.525)$, 窗格 平板藻的衰退趋势较为强烈 $(R=-0.640)$, 棒形鼓藻的衰退趋势较弱 $(R=-0.379)$, 水绵藻一种的衰退趋势 最弱 $(R=-0.065)$. 空间维度上, 钝脆杆藻的发展趋势最为强烈 $(R=1.218)$, 克洛脆杆藻的发展趋势较为强 烈 $(R=0.492)$, 缢缩异极藻 $(R=0.368)$ 、窗格平板藻 $(R=0.307)$ 和尖针杆藻 $(R=0.301)$ 的发展趋势较弱, 棒 形鼓藻的发展趋势最弱 $(R=0.146)$; 偏肿桥弯藻的衰退趋势最为强烈 $(R=-0.788)$, 水绵藻一种的衰退趋势 最弱 $(R=-0.045)$. 时空维度上, 只有水绵藻一种属于衰退趋势 $(R=-0.045)$, 其他优势种中窗格平板藻的发 展趋势最为强烈 $(R=0.275)$, 其次是偏肿桥弯藻的发展趋势 $(R=0.125)$, 钝脆杆藻和缢缩异极藻的发展趋势 
较为强烈 $(R=0.097)$, 克洛脆杆藻 $(R=0.078)$ 和尖针杆藻 $(R=0.068)$ 的发展趋势较弱, 棒形鼓藻的发展趋势 最弱 $(R=0.059)$. 从总体上看, 麦地卡湿地浮游植物优势种在时间维度上生态响应速率之和为负数 $(-4.4)$, 在空间维度上生态响应速率之和为正数 (1.999), 在时空维度上生态响应速率之和为正数 $(0.782)$, 表明该 湿地浮游植物群落处于发展阶段, 尚未演替至成熟阶段.

\section{5 生态位分化}

麦地卡湿地不同样点间水温在 $6.01 \sim 11.71^{\circ} \mathrm{C}$ 之间; 水体 $\mathrm{pH}$ 为 $8.10 \sim 9.05$, 整体偏碱性; EC、Salt、TDS、 TUR 和 $\mathrm{COD}_{\mathrm{Cr}}$ 浓度在不同样点间差异显著 $(P<0.05) ; \mathrm{DO} 、 \mathrm{TN} 、 \mathrm{NH}_{3}-\mathrm{N} 、 \mathrm{TP}$ 和 $\mathrm{NO}_{3}^{-}-\mathrm{N}$ 浓度在不同样点间差异 不显著; $\mathrm{TN} 、 \mathrm{TP}$ 和 $\mathrm{NH}_{3}-\mathrm{N}$ 等营养物质浓度整体较低.

对麦地卡湿地浮游植物优势种细胞丰度与各环境因子间的关系进行去除趋势对应分析 (DCA), 结果排 序轴长度小于 3 , 表明研究浮游植物优势种与各环境因子的关系需采用圥余分析 (redundancy analysis, RDA) , 共有 12 个环境因子 $\mathrm{NO}_{3}^{-}-\mathrm{N} 、 \mathrm{pH} 、 \mathrm{EC} 、 \mathrm{TDS} 、 \mathrm{COD}_{\mathrm{Cr}} 、 S a l t 、 W T 、 \mathrm{DO} 、 \mathrm{TUR} 、 \mathrm{TN} 、 \mathrm{TP}$ 和 $\mathrm{NH}_{3}-\mathrm{N}$. 应用蒙特卡拟 合方法对环境因子进行显著性检验, 笁选出 $\mathrm{pH}(P=0.022, F=3.9) 、 \mathrm{DO}(P=0.022, F=3.2) 、 \mathrm{TN}(P=0.022$, $F=4.1)$ 和 TUR $(P=0.038, F=10.1)$ 是显著解释性变量, 对优势种的解释率分别为 $24.5 \% 、 17.0 \% 、 14.5 \%$ 和 $6.8 \%$, 是影响麦地卡湿地浮游植物优势种生态位的主要环境因子, 影响并不显著的环境因子用虚线表示, 结 果如图 3 所示.

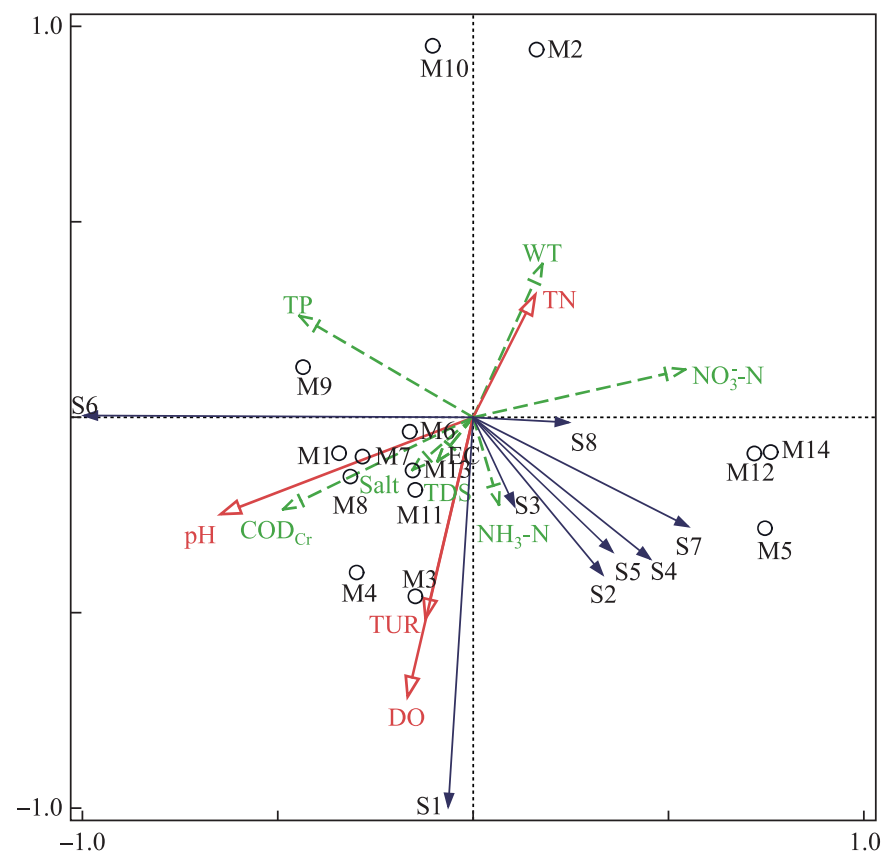

图 3 麦地卡浮游植物优势种与环境因子的 RDA 分析

Fig.3 RDA analysis of dominant phytoplankton species and environmental factors in Mitika Wetland

分析图 3 可得,第一、二排序轴的特征值分别为 0.530 和 0.333 ,物种一环境累计方差的解释率分别为 $52.99 \%$ 和 $33.29 \%$, 物种一环境因子的相关系数分别为 0.999 和 $>0.999$, 前两轴累计方差为 $86.72 \%$, 表明前两 轴能较好地反映麦地卡湿地浮游植物优势种与各环境因子的关系, 且主要是由第一排序轴决定; $\mathrm{NO}_{3}^{-}-\mathrm{N}_{\text {聚 }}$ 集在第一排序轴的正轴, 与第一排序轴呈最大正相关, $\mathrm{pH}$ 聚集在第一排序轴的负轴, 与第一排序轴呈最大 负相关; 其中, 缢缩异极藻、尖针杆藻和窗格平板藻聚集在第一排序轴的正轴, 与 $\mathrm{NO}_{3}^{-}-\mathrm{N}$ 浓度呈明显正相关, 说明 $\mathrm{NO}_{3}^{-}-\mathrm{N}$ 浓度是影响其分布的最主要因素. WT 和 $\mathrm{TN}$ 聚集在第二排序轴的正轴, 与第二排序轴呈较大正 相关, DO 和 TUR 聚集在第二排序轴的负轴,与第二排序轴呈较大负相关,其中, 水绵藻一种与 TP 浓度呈明 显正相关, 说明 TP 浓度对水绵藻一种的分布有较大影响. 


\section{4 讨论}

\section{1 时间、空间及时空维度生态位宽度分析}

浮游植物对外界环境变化具有敏感的反应, 因此可指示水体的营养类型 ${ }^{[38]}$. 在本研究中优势种共有 8 种,其中 6 种属于硅藻门, 2 种属于绿藻门,显示麦地卡湿地水体为贫营养型. 主要原因可能是大多数硅藻都 是狭冷性物种, 适合在较寒冷和贫营养的水环境中生活 ${ }^{[39]}$. 而麦地卡湿地处于高寒缺氧地带 (平均海拔 $4900 \mathrm{~m}$ ), 浮游植物常年在较低温 (年平均气温为 $0.9^{\circ} \mathrm{C}$ ) 水环境下生存, 已形成了动态的适应性机制, 这一 结果与西藏其他地区水生生物的研究结果报道相一致 ${ }^{[38-39]}$. 根据《地表水环境质量标准》 (GB $3838-$ 2002), TN、TP 和 $\mathrm{NH}_{3}-\mathrm{N}$ 等营养物质浓度整体较低, 甚至个别样点的数值出现了标准下限值. 原因可能是麦 地卡湿地的补给水主要以高山冰川融雪、地下水和天然降水为主, 外源营养物质来源相对单一和贯乏, 使得 湿地内营养物质浓度普遍较低,这与优势种对水环境营养类型的评价一致.

种群在时间维度上的分布反映了物种与资源随时间变化的多维动态依存关系 ${ }^{[5]}$, 时间生态位宽度值的 大小反映的是物种出现时间的长短, 时间生态位宽度值越大, 说明物种在时间序列上分布较均匀; 反之, 说 明物种在时间序列上分布呈波动性, 具有明显的高峰期 (季节性) ${ }^{[7]}$. 水绵藻一种的时间生态位宽度值最大, 说明该物种在麦地卡湿地出现的时间最长 (具有较强的竞争力), 为麦地卡湿地 2 个水情期中的广泛种. 水 绵藻一种以群体的方式存在, 在获取营养盐上具有明显的优势, 对水温变化明显, 且广泛分布于河流、湖泊 和水库中, 对寡污到 $\beta$-中污的水体具有指示作用 (表 8 ). 本研究中样地类型多样,包括湖泊、河流和沼泽, 属 于高原亚寒带半湿润气候, 对 2 个水情期的温度产生影响. 因水绵藻一种自身具有较强的生态适应性, 故虽 然其出现频率和丰度值在 8 个优势种中不是最大, 但生态位宽度值还是最大, 原因可能是该物种自身适应 多样化生境的资源能力较强和麦地卡多样性化的生境适合水绵藻一种生长. 这与李世健等 ${ }^{[40]}$ 对长江中游 段浮游植物周年变化的结论和王宏伟等 ${ }^{[41]}$ 研究的结论基本一致. 偏肿桥弯藻的时间生态位宽度值最小, 说 明该物种在麦地卡湿地出现的时间最短. 从藻类的出现频率和丰度分析, 偏肿桥弯藻在 2 个水情期中都较 小,这可能是其时间生态位宽度值最小的原因. 吴佳梦等 ${ }^{[15]}$ 对浙江舟山定海护城河浮游植物优势种生态位 与种间联结性季节性分析和杨文焕等 ${ }^{[42]}$ 的研究结果基本与本结论相似.

空间生态位宽度可以反映物种在空间维度上的分布范围和均匀程度 ${ }^{[8]}$. 空间生态位宽度值越大, 说明 物种在空间分布上越广泛和越均匀; 反之, 说明物种在空间分布上呈波动性, 具有明显的高峰期 (区域 性 $)^{[42]}$. 本研究中, 克洛脆杆藻的空间生态位宽度值最大, 说明其在麦地卡湿地的分布最广泛, 与其它物种 竞争能力也最强. 由表 8 可知, 克洛脆杆藻对寡污到 $\beta$-中污的水体都具有指示作用, 根据其在麦地卡湿地出 现频率和丰度分析, 也能说明其适应多样化生境的资源能力较强. 偏肿桥弯藻的空间生态位宽度值最小, 说 明其在麦地卡湿地的分布最狭窄, 为麦地卡湿地的指示种. 根据偏肿桥弯藻在麦地卡湿地 14 个样点的出现 频率和丰度可知, 其只存在于某些生境, 原因可能是其适应多样化生境的能力较弱且对水环境条件变化比 较敏感. 杨文焕等 ${ }^{[42]}$ 通过对冻融期包头南海湖浮游植物群落及优势种的生态分析得到物种的丰度越大, 生 态位宽度值就越大, 反之则越小. 这与郭坤等 ${ }^{[16]}$ 和本文的研究结论基本一致.

时空二维生态位更能准确的反映物种对时间和空间资源的利用程度 ${ }^{[3]}$. 由于麦地卡湿地浮游植物优势 种的时间生态位宽度差别不大 (极差:0.124), 故时空二维生态位宽度的变化幅度 (极差:0.115) 受空间维度 生态位的宽度 (极差: 0.421 ) 影响比较明显, 即不同生境对麦地卡湿地浮游植物优势种的出现频率和丰度变 化影响比较大, 这与徐开达等 ${ }^{[5]}$ 和刘坤等 ${ }^{[11]}$ 的研究结论基本一致. 在空间维度上, 克洛脆杆藻的出现频率 和丰度最大, 其次是水绵藻一种, 在时空维度上也是, 这也从侧面证明了时空生态位的宽度值变化主要受空 间生态位宽度值的影响.

根据各优势种在时空不同维度上的聚类分析结果表明, 在时间维度上, 广生态位类群有水绵藻一种, 在 空间维度上, 是克洛脆杆藻, 在时空维度上, 是克洛脆杆藻和水绵藻一种, 此类优势物种对水环境的适应能 力较强, 环境因素对其分布限制较弱; 在时间维度上, 中生态位类群有窗格平板藻, 在空间及时空不同维度 上, 有窗格平板藻、尖针杆藻、棒形鼓藻和䍀缩异极藻, 此类优势物种对环境的适应能力稍差于广生态位类 群, 环境因素对其有一定的限制性, 如窗格平板藻的最适生长季节为春、夏、冬季 (表 8); 在时间维度上, 窄生 
态位类群有尖针杆藻、䌾缩异极藻、钝脆杆藻、棒形鼓藻和克洛脆杆藻; 在空间及时空不同维度上, 有水绵藻 一种、钝脆杆藻和偏肿桥弯藻, 此类类群的生态位宽度值最小, 说明环境因子对其分布限制最大, 但从表 8 可知偏肿桥弯藻、缢缩异极藻、尖针杆藻在塞污到 $\alpha$-中污的水体都有分布, 说明麦地卡湿地特殊的水体环境 (贫营养型) 影响了这些物种的生长繁殖, 在特定的生境下, 限制浮游植物对生境的适应能力, 但不代表这类 物种就是对环境适应性差的敏感种. 浮游植物的生态位宽度指数, 在一定程度上反映了该湿地在不同环境 条件下物种的生态习性差异, 也印证了生态位宽度指数是判定物种优势度大小的一个重要指标 ${ }^{[16]}$.

表 8 浮游植物优势种的形态特征和生态习性

Tab.8 Morphological characteristics and ecological habits of dominant phytoplankton species

\begin{tabular}{|c|c|c|c|c|c|}
\hline 物种 & 大小/ $\mu \mathrm{m}$ & $\begin{array}{c}\text { 单细胞/ } \\
\text { 群体 }\end{array}$ & 最适季节 & 生活型 & 参考文献 \\
\hline 偏肿桥弯藻 & $\mathrm{L}: 10 \sim 40, \mathrm{~W}: 3 \sim 12$ & 单细胞 & 春、秋、冬季 & 生长于寡污到 $\alpha$-中污的水体 & {$[43-49]$} \\
\hline 钝脆杆藻 & $\mathrm{L}: 25 \sim 220, \mathrm{~W}: 2 \sim 7$ & 单细胞 & 四季 & 生长于寡污到 $\beta$-中污的水体 & {$[44,46-48,50-52]$} \\
\hline 克洛脆杆藻 & $\Phi: 0.99 \sim 3.66$ & 单细胞 & 四季 & 生长于寡污到 $\beta$-中污的水体 & {$[42,51]$} \\
\hline 缢缩异极藻 & $\mathrm{L}: 25 \sim 65, \mathrm{~W}: 4.5 \sim 14$ & 单细胞 & 四季 & 生长于寡污到 $\alpha$-中污的水体 & {$[49,53]$} \\
\hline 棒形鼓藻 & $\mathrm{L}: 82 \sim 284, \mathrm{~W}: 6 \sim 17$ & 单细胞 & 春、秋季 & 生长于寡污的水体 & {$[42,48,54]$} \\
\hline 水绵藻一种 & $\mathrm{L}: 36 \sim 78, \mathrm{~W}: 18 \sim 31$ & 群体 & 夏、秋季 & 生长于寡污到 $\beta$-中污的水体 & {$[44,46,52]$} \\
\hline 尖针杆藻 & $\mathrm{L}: 62 \sim 300, \mathrm{~W}: 3 \sim 6$ & 单细胞 & 春、夏、冬季 & 生长于寡污到 $\alpha$-中污的水体 & {$[45-50,52-53]$} \\
\hline 窗格平板藻 & $\mathrm{L}: 20.5 \sim 140, \mathrm{~W}: 3 \sim 9$ & 单细胞 & 春、夏、冬季 & 生长于寡污到 $\beta$-中污的水体 & {$[43,46]$} \\
\hline
\end{tabular}

$* L 、 W 、 \Phi$ 分别表示长度、宽度和直径.

\section{2 时间、空间及时空维度生态位重叠分析}

生态位重叠反映了不同物种之间对资源利用的相似程度以及潜在的竞争关系 ${ }^{[11-12]}$. 时间生态位重叠反 映了不同物种对时间资源利用的相似程度 ${ }^{[15]}$. 在时间维度上, 钝脆杆藻和克洛脆杆藻、缢缩异极藻和棒形 鼓藻的生态位重叠值最高, 表明钝脆杆藻和克洛脆杆藻 (缢缩异极藻和棒形鼓藻) 在研究湿地内对资源利用 的时间同步性最强, 竞争也最激烈, 钝脆杆藻和克洛脆杆藻在 2 个水情期都出现, 且丰度都是在枯水期 $\left(13.958 \times 10^{4} 、 83.880 \times 10^{4} \mathrm{cells} / \mathrm{L}\right)$ 远大于丰水期 $\left(7.375 \times 10^{4} 、 46.674 \times 10^{4} \mathrm{cells} / \mathrm{L}\right)$; 䍀缩异极藻和棒形鼓藻在 2 个水情期也都出现，且丰度都是枯水期 $\left(7.399 \times 10^{4} 、 9.538 \times 10^{4} \mathrm{cells} / \mathrm{L}\right)$ 小于丰水期 $\left(15.484 \times 10^{4} 、 21.608 \times\right.$ $10^{4} \mathrm{cells} / \mathrm{L}$ ) ; 二对物种的生态位重叠值与浮游植物分布的时间 (水情期) 重合情况相一致, 该结论与 Wathne 等 ${ }^{[55]}$ 提出的 “种间生态位重叠较显著时, 物种出现的站点重合度较高” 的结论相符合. 麦地卡湿地两个季节 浮游植物群落优势种重叠值高 $\left(O_{i k} \geqslant 0.6\right)$ 的种对为 $89.29 \%$, 种对间达到有意义重叠的水平较高, 本研究中, 大部分浮游植物分布的季节性差异较大, 偏肿桥弯藻、缢缩异极藻、尖针杆藻和棒形鼓藻的丰度都是暖季大 于冷季, 钝脆杆藻、克洛脆杆藻、窗格平板藻和水绵藻一种的丰度都是冷季大于暖季, 表明麦地卡湿地大部 分浮游植物对时间资源的利用接近程度较高, 因此呈现出浮游植物优势种的时间生态位重叠较高的现象. 郭坤等 ${ }^{[16]}$ 对于湖北省长湖浮游植物优势种生态位的分析和吴佳梦等 ${ }^{[15]}$ 的研究结论与上述观点较一致.

空间生态位重叠反映不同物种对空间资源利用的相似程度 ${ }^{[5]}$, 䍀缩异极藻和尖针杆藻的空间生态位重 叠值最高, 说明二者在该调查湿地空间资源分布上的同域性最强, 对资源的竞争也最激烈. 原因可能是这两 种藻类同属于硅藻门, 都能指示从寡污到 $\alpha$-中污的水体, 且大小基本相似, 对营养盐成分的获取也基本相似 (表 8), 从而产生了激烈的竞争关系. 在复杂的生物群落中, 各物种的生态位总是倾向于分享其它物种的基 础生态部分, 引起多个物种对某些资源的共同需求, 使不同物种的生态位之间常处于不同程度的重叠状 态 $^{[16]}$. 偏肿桥弯藻和棒形鼓藻生态位重叠值较高, 说明两者具有较强的竞争关系, 两者空间范围上的相似 性可能与所需资源相关, 因为当同一生境中资源不足时会产生食物资源竞争, 虽然偏肿桥弯藻和棒形鼓藻 属于不同门类, 但在资源上的需求有很大相似, 故具有较强的竞争关系. 这与杨文焕 等 $^{\left[{ }^{56]}\right.}$ 对包头南海湖浮 游植物优势种生态位分析得出的结论基本一致. 空间生态位重叠最低的种对为水绵藻一种和尖针杆藻, 可 能与这 2 种浮游植物在样点分布上有较大差异有关, 水绵藻一种在枯水期为优势种, 尖针杆藻在丰水期为 
优势种, 导致二者之间竞争性不明显. 李兴等 ${ }^{[10]}$ 对内蒙古乌梁素海浮游植物优势种的生态位分析和杨文焕 等 ${ }^{[56]}$ 的研究结果与上述结论相符. 在本研究湿地除一对种对为没有意义的重叠, 其它种对的重叠值都有意 义, 表明麦地卡湿地浮游植物优势种在空间分布上相似性极高, 种内和种间都存在强烈的竞争关系.

时空二维生态位重叠值为时间、空间生态位重叠值的乘积, 其计测结果能更好地衡量种间的关系 ${ }^{[9]}$. 时 空二维生态位重叠值最大的种对是缢缩异极藻和尖针杆藻, 说明这两者的时间同步性与空间同域性较强, 对时空二维资源的利用趋于一致,存在种间竞争或共存关系,在生物资源丰富时,两者时共存的关系,在生 物资源不充足时, 两者竞争激烈. 这与夏霆等 ${ }^{[57]}$ 对镇江通江城市河道浮游植物优势种群生态位分析和安瑞 志等 ${ }^{[17]}$ 对巴松措 (湖) 夏季浮游植物优势种群分布格局与共存机制研究结果基本较一致; 偏肿桥弯藻和棒 形鼓藻的时空二维生态位重叠值较大, 说明这两者具有一定的时间同步性与空间同域性,物种间相关性较 高. 两者都只在丰水期为优势种, 偏肿桥弯藻在 2 个水情期出现频率分别为 $78.57 \%$ 和 $64.29 \%$, 丰度分别为 $9.102 \times 10^{4}$ 和 $5.426 \times 10^{4} \mathrm{cells} / \mathrm{L}$, 棒形杆藻在 2 个水情期出现频率分别为 $100 \%$ 和 $78.57 \%$, 丰度分别为 $21.608 \times 10^{4}$ 和 $9.538 \times 10^{4} \mathrm{cells} / \mathrm{L}$. 水绵藻一种和尖针杆藻的时空二维生态位重叠值最小, 说明二者时空异质 性较高, 物种间相关性较低, 从上面时间和空间维度也可以看出水绵藻一种和尖针杆藻对不同生境和季节 具有生态适应差异; 此外, 麦地卡湿地时空二维生态位显著重叠的种对占总种对数的 $28.57 \%$, 无意义重叠值 的种对占总种对数的 $10.71 \%$, 说明该湿地浮游植物优势种间的时空分布差异较小, 对时空资源需求异质性 低,物种间潜在竞争关系较强,该结论与安瑞志等 ${ }^{[17]}$ 的结论相符.

\section{3 生态位分化与生态响应速率分析}

种群呈发展或衰退趋势是不同种群竞争的直接结果, 是生物与非生物因子的相互作用的生态响应 ${ }^{[58]}$. 在时间维度上, 克洛脆杆藻有最大的发展空间, 但发展响应速率最小; 在空间和时空维度上, 棒形鼓藻有最 大的发展空间, 但发展响应速率最小; 说明克洛脆杆藻在 2 个水情期、棒形鼓藻在不同样点与其它优势种在 资源竞争上占据优势地位, 但在发展过程中发展趋势会变缓, 这也说明发展趋势较强优势种为了获得更多 的生态资源可能会通过增大生态位来增强种间竞争力, 但是随着种群不断发展, 环境承载力和种内竞争不 断增强会导致其发展速度放缓; 同样,衰退型种群, 如水绵藻一种在时间、空间以及时空维度上均为衰退优 势种, 但是其生态响应速率较小, 表明其衰退趋势也会变缓. 在时间维度上, 尖针杆藻有最小的发展空间,但 发展响应速率最大, 在空间维度上, 钝脆杆藻也是发展空间最小, 发展响应速率最大, 窗格平板藻在时空维 度上发展空间最小, 但发展速率最大. 反之, 缢缩异极藻在时间维度上有最小的衰退空间, 但衰退响应速率 最大, 在空间维度上, 偏肿桥弯藻有最小的衰退空间, 但衰退速率最大, 这说明发展 (衰退) 趋势较弱优势种 为了加强自身的生态适应性会增大物种的相对资源占有量, 反之, 会减少物种对资源的相对占有量. 杨文焕 等 ${ }^{[42]}$ 通过对冻融期包头南海湖浮游植物群落及优势种的生态分析和安瑞志等 ${ }^{[17]}$ 通过对巴松措 (湖) 夏季浮 游植物优势种群分布格局与共存机制的研究得到的结论与上述观点基本一致.

浮游植物在不同环境因子下发生生态位分化, 可以通过排序的手段来解释物种一环境因子间的关系, 从 而对生态位测度计算得到的结果进行补充说明 ${ }^{[58]}$. 排序图轴 1 反映了硝态氮、总磷、酸碱度和化学需氧量的 变化, 对浮游植物产生直接影响; 轴 2 反映了水温、总氮、浊度、溶解氧和氨氮的变化, 对浮游植物产生间接 影响; 因此, 前者是影响其空间生态位分化的主要因子, 后者是影响其空间生态位分化的次要因子. 分析 $\mathrm{RDA}$ 图可知, $\mathrm{pH} 、 \mathrm{DO} 、 \mathrm{TN}$ 和 TUR 是显著性解释麦地卡湿地空间生态位分化的变量, 这与黄香等 ${ }^{[23]}$ 对西藏麦 地卡湿地表层沉积物元素分布特征分析和陈虎林等 ${ }^{[59]}$ 对西藏麦地卡湿地水化学特征初探的研究结果较一 致. 麦地卡湿地水体整体呈碱性, 溶解氧和总氮是藻类生长和繁殖的必要条件. 偏肿桥弯藻和水绵藻一种生 态位分化较为明显, 一方面原因可能是偏肿桥弯藻和水绵藻一种自身对生境的适应性及对营养盐的获取存 在差异, 偏肿桥弯藻以单细胞的形式存在, 个体较小, 但能指示从寡污到 $\alpha$-中污的水体; 而水绵藻一种以群 体的形式存在, 个体较大, 能更多更快的获取营养盐, 但对季节变化非常敏感 (在夏、秋季生长最适), 指示从 寡污到 $\beta$-中污的水体 (表 8 ), 故生态位重叠度很低. 另一方面, 水绵藻一种虽也在冷暖季节都有分布, 但其 丰度受到空间影响较大, 故与其它浮游植物差异较大, 因此, 造成了与其它浮游植物在 RDA 排序图距离远、 生态位分化高和重叠度较低的结果. 


\section{5 结论}

本文分析了麦地卡湿地浮游植物优势种时空不同维度 (时间、空间及时空) 上生态位的宽度和重叠情 况,结合几余分析和生态响应速率探讨了浮游植物优势种的生态位分化. 得出以下结论: 1) 麦地卡湿地浮游 植物的生态位宽度以克洛脆杆藻为主的一类最大, 其次是以䍀缩异极藻、棒形鼓藻等为主的一类, 偏肿桥弯 藻和钝脆杆藻为主的一类最小. 2) 在时间维度上, 浮游植物优势种的生态位重叠值以高等级为主, 在空间维 度上, 以高、中两个等级为主, 在时空维度上以中等等级为主. 3) 浮游植物优势种在时间维度上生态响应速 率之和为负数 $(-4.4)$, 在空间维度上生态响应速率之和为正数 (1.999), 表明该湿地浮游植物群落处于发展 阶段, 尚未演替至成熟阶段. 4) 影响麦地卡湿地浮游植物优势种生态位的主要环境因子是 $\mathrm{pH} 、 \mathrm{DO} 、 \mathrm{TN}$ 和 TUR, 对优势种的解释率分别为 $24.5 \% 、 17.0 \% 、 14.5 \%$ 和 $6.8 \%$.

\section{6 参考文献}

[ 1 ] An RZ, Pan CM, Taba LZ et al. Vertical distribution characteristics of phytoplankton functional groups and their relationships with environmental factors in Lake Basomtso, Tibet, China Tibet, China. J Lake Sci, 2021, 33(1) : 86-101. DOI: 10.18307/2021.0114. [安瑞志, 潘成梅, 塔巴拉珍等. 西藏巴松错浮游植物功能群垂直分布特征及其与环境因子 的关系. 湖泊科学, 2021, 33(1): 86-101.]

[ 2 ] Zhang M, Yu Y, Qian SQ et al. Phytoplankton community structure and biodiversity in summer Yunnan-Guizhou Plateau lakes. J Lake Sci, 2010, 22(6) : 829-836. DOI: 10.18307/2010.0604. [张民, 于洋, 钱善勤等. 云贵高原湖泊夏季 浮游植物组成及多样性. 湖泊科学, 2010, 22(6) : 829-836.]

[ 3 ] Miao ZB, Wang SK, Peng BB et al. Characteristics of spatial and temporal ecological niches of the dominant species of fish assemblages in the saltmarsh wetlands of the Yangtze Estuary. Journal of Fishery Sciences of China, 2020, 27(10) : 12101221. DOI: 10.3724/SP.J.1118.2020.20010. [苗中博, 王思凯, 彭彪彪等. 长江口盐沼湿地鱼类群落优势种的时空 生态位特征. 中国水产科学, 2020, 27(10): 1210-1221.]

[ 4 ] Peng WJ, Wang XM. Concept and connotation development of niche and its ecological orientation. Chinese Journal of Applied Ecology , 2016, 27 (1) : 327-334. DOI : 10.13287/j.1001-9332.201601.005. [彭文俊, 王晓鸣. 生态位概念和内 涵的发展及其在生态学中的定位. 应用生态学报, 2016, 27 (1) : 327-334.]

[ 5 ] Xu KD, Lu LE, Lu ZH et al. Niche of dominant species of shrimp in Jiushan Archipelago Nature Reserve. Biodiversity Science, 2018, 26(6) : 601-610. DOI: 10.17520/biods.2017339. [徐开达, 卢衍尔, 卢占晖等. 非山列岛自然保护区虾 类优势种生态位. 生物多样性, 2018, 26(6): 601-610.]

[ 6 ] Wang ZL, Chen Y, Chen XM et al. Temporal-spatial niches of Chinese White Wax Scale insect (Ericerus pela) and its three dominant parasitoid wasps. Acta Ecologica Sinica, 2011, 31(4) : 914-922. DOI: 10.3724/SP.J.1141.2008.06661. [王自力, 陈勇, 陈晓鸣等. 白蜡虫及其 3 种优势寄生蜂的时空生态位. 生态学报, 2011, 31(4) : 914-922.]

[ 7 ] Wei ZB, Chai Y, Luo JB et al. Seasonal succession and ecological niche analysis of the dominant species of phytoplankton in Changhu lake. Acta Hydrobiologica Sinica, 2020, 44(3) : 612-621. DOI: 10.7541/2020.075. [魏志兵, 柴毅, 罗静 波等. 长湖浮游植物优势种季节演替及生态位分析. 水生生物学报, 2020, 44(3): 612-621.]

[ 8 ] Xu CY, Yu QJ, Xu FJ et al. Niche analysis of phytoplankton's dominant species in Dianshan Lake of East China. Chinese Journal of Applied Ecology, 2012, 23(9) : 2550-2558. DOI: 10.13287/j.1001-9332.2012.0358. [徐春燕, 俞秋佳, 徐 凤洁等. 淀山湖浮游植物优势种生态位. 应用生态学报, 2012, 23(9) : 2550-2558.]

[ 9 ] Yu ZH, Jin XS, Li XS. Analysis of ecological niche for major fish species in the central and southern Yellow Sea. Marine Fisheries Research, 2010, 31(6): 1-8. [于振海, 金显仕, 李显森. 黄海中南部主要鱼种的生态位分析. 渔业科学进 展, 2010, 31(6): 1-8.]

[10] Li X, Li JR, Li CY. Ecological niche analysis of dominant phytoplankton species in Wuliangsuhai Lake, Inner Mongolia. Journal of Hydroecology, 2017, 38(6) : 40-47. DOI: 10.15928/j.1674-3075.2017.06.006. [李兴, 李建茹, 李畅游. 内 蒙古乌梁素海浮游植物优势种的生态位分析. 水生态学杂志, 2017, 38(6) : 40-47.]

[11] Liu K, Yu CG, Xu YJ et al. Spatio-temporal niche of major fish species in Pishan waters off Zhejiang Province, China. Chinese Journal of Applied Ecology, 2021, 32(3) : 1069-1079. DOI: 10.13287/j.1001-9332.202103.033. [刘坤, 俞存 根, 许永久等. 浙江披山海域主要鱼类时空生态位. 应用生态学报, 2021, 32(3) : 1069-1079.] 
[12] Liu MH, Liang J, Xu HX. Spatio-temporal niche of dominant shrimp species in the Zhongjieshan Islands Marine Protected Area, China. Chinese Journal of Applied Ecology, 2020, 31(5) : 1746-1752. DOI: 10.13287/j.1001-9332.202005.036. [刘明华, 梁君, 徐汉祥. 中街山列岛海洋保护区虾类优势种时空生态位. 应用生态学报, 2020, 31 ( 5): 1746-1752.]

[13] Cai YC, Sun MS, Xu YW et al. Dominant species of cephalopods and their niche characteristics in offshore of northern South China Sea. Chinese Journal of Applied Ecology, 2020, 31 ( 8) : 2793-2803. DOI: 10.13287/j.1001-9332.202008. 031. [蔡研聪, 孙铭帅, 许友伟等. 南海北部近海头足类优势种及其生态位特征. 应用生态学报, 2020, 31 (8): 2793-2803.]

[14] Hou QW, Bai HY, Tie J. Niche characteristics of moth community in Manghe National Nature Reserve. Chinese Journal of Ecology, 2015, 34(4) : 1038-1045. DOI: 10.13292/j.1000-4890.20150311.059. [侯沁文, 白海艳, 铁军. 蟒河猕猴 国家级自然保护区蛾类群落生态位特征. 生态学杂志, 2015, 34(4) : 1038-1045.]

[15] Wu JM, Xu NN, Zhang WJ et al. Seasonal analysis of the niche and interspecific association of dominant species of phytoplankton in the Dinghai Moat, Zhoushan City. J Lake Sci, 2019, 31(2) : 429-439. DOI: 10.18307/2019.0212. [吴佳 梦, 徐娜娜, 张文珺等. 浙江舟山定海护城河浮游植物优势种生态位与种间联结性季节性分析. 湖泊科学, 2019, 31(2) : 429-439.]

[16] Guo K, Yang DG, Peng T et al. Ecological niche analysis of dominant species of phytoplankton in Lake Changhu, Hubei Province. J Lake Sci, 2016, 28(4) : 825-834. DOI: 10.18307/2016.0416. [ 郭坤, 杨德国, 彭婷等. 湖北省长湖浮游 植物优势种生态位分析. 湖泊科学, 2016, 28(4): 825-834.]

[17] An RZ, Pan CM, Liu Y et al. Study on the distribution pattern and coexistence mechanism of dominant summering phytoplankton population in the Basomtso. Plateau Science Research, 2020, 4(2): 27-36. [安瑞志, 潘成梅, 刘洋等. 巴松措 (湖) 夏季浮游植物优势种群分布格局与共存机制研究. 高原科学研究, 2020, 4(2): 27-36. ]

[18] Xing Y, Jiang QG, Li WQ et al. Landscape spatial patterns changes of the wetland in Qinghai-Tibet Plateau. Ecology and Environmental Sciences, 2009, 18(3) : 1010-1015. [邢宇, 姜琦刚, 李文庆等. 青藏高原湿地景观空间格局的变化. 生态环境学报, 2009, 18(3): 1010-1015.]

[19] Zhong XH, Liu SZ, Wang XD et al. A research on the protection and construction of the state ecological safe shelter zone on the Tibet Plateau. Journal of Mountain Science, 2006, 24(2) : 129-136. [ 钟祥浩, 刘淑珍, 王小丹等. 西藏高原国 家生态安全屏障保护与建设. 山地学报, 2006, 24(2): 129-136.]

[20] Zhu WZ, Zhong XH, Fan JR. Characteristics of wetland ecosystem in Tibet Plateau and its protection countermeasures. Journal of Mountain Science, 2003, (S1) : 7-12, 39. [ 朱万泽, 钟祥浩, 范建容. 西藏高原湿地生态系统特征及其保 护对策. 山地学报, 2003, (S1) : 7-12, 39.]

[21] Lan JJ, Luo J. Diversity of seed plant resources in maidica wetland natural reserve in Tibet. Journal of Plateau Agriculture, 2018, 2 (1) : 19-25. [拦继酒, 罗建. 西藏麦地卡湿地自然保护区种子植物资源多样性. 高原农业, 2018, 2(1) : 19-25.]

[22] An RZ, Zhang P, Da Z et al. Niche and interspecific association of dominant protozoan species under different hydrologic periods in the Mitika Wetland of Tibet, China. Scientia Silvae Sinicae, 2021, 57(2): 126-138. [安瑞志, 张鹏, 达珍等. 西藏麦地卡湿地不同水文期原生动物优势种生态位及其种间联结性. 林业科学, 2021, 57(2) : 126-138.]

[23] Huang X, Mi J, Ren Z et al. Distribution and pollution risk assessment of trace elements in the surface sediments of Mitika Wetland, Tibet. Environmental Ecology, 2020, 2(11): 1-6, 24. [黄香, 米加, 仁珍等. 西藏麦地卡湿地表层沉积物 元素分布特征及其污染风险评价. 环境生态学, 2020, 2(11): 1-6, 24.]

[24] Zhang ZS, Huang XF eds. Research methods of freshwater plankton. Beijing: Science Press, 1991. DOI: 10.4236/ijamsc. 2014.23008. [ 章宗涉, 黄祥飞. 淡水浮游生物研究方法. 北京: 科学出版社, 1991.]

[25] Chi NW ed. Atlas of Bacillariophyta in Tibet. Lhasa: Tibet People's Publishing House, 1990. [迟若文. 西藏硅藻图集. 拉萨: 西藏人民出版社, 1990.]

[26] The Qinghai-Tibet Plateau Comprehensive Scientific Expedition of Chinese Academy of Sciences ed. Tibet algae. Beijing: Science Press, 1992. [中国科学院青藏高原综合科学考察队. 西藏藻类. 北京: 科学出版社, 1992.]

[27] Zhu HZ, Chen JY eds. Bacillariophyta of the Xizang Plateau. Beijing: Science Press, 2000. [朱㯖忠, 陈嘉佑. 中国西 藏硅藻. 北京: 科学出版社, 2000.]

[28] Hu HJ, Wei YX eds. Chinese freshwater algae—system, classification and ecology. Beijing: Science Press, 2006. [胡鸿 
钧, 魏印心. 中国淡水藻类系统分类及生态. 北京: 科学出版社, 2016.]

[29] McNaughton SJ. Relationships among functional properties of Californian grassland. Nature, 1967, 216(5111) : 168-169. DOI : $10.1038 / 216168 \mathrm{~b} 0$.

[30 ] Habib OA, Tippett R, Murphy KJ. Seasonal changes in phytoplankton community structure in relation to physico-chemical factors in Loch Lomond, Scotland. Hydrobiologia, 1997, 350(1/2/3) : 63-79. DOI: 10.1023/ A : 1003037012226.

[31] Liang M, Sun LY, Jiang Q et al. Net-phytoplankton community structure characteristics and its correlation with environmental factors in coastal waters of Caofeidian. Journal of Applied Oceanography, 2019, 38(2) : 252-265. [梁沝, 孙丽艳, 姜倩等. 曹妃甸近岸海域网采浮游植物群落结构特征 及其与环境因子的相关性研究. 应用海洋学学报, 2019, 38 (2) : 252-265.]

[32] Wang JY, Wang ZC, Li C et al. The spatio-temporal dynamics of phytoplankton community structure in the head region of the Three Gorges reservoir. Acta Hydrobiologica Sinica, 2015, 39(5) : 877-884. DOI: 10.7541/2015.116. [王静雅, 汪 志聪, 李朋等. 三峡水库坝前水域浮游植物群落时空动态研究. 水生生物学报, 2015, 39(5): 877-884.]

[33] Colwell RK, Futuyma DJ. On the measurement of niche breadth and overlap. Ecology, 1971, 52 (4) : 567-576. DOI: 10. 2307/1934144.

[34] Pianka ER. The structure of lizard communities. Annual Review of Ecology and Systematics, 1973, 4(1) : 53-74. DOI: 10. 1146/annurev.es.04.110173.000413.

[35] Krebs CJ ed. Ecological methodology. New York: Harper Collins Publishers, 1989. DOI: 10.4236/jep.2011.24038.

[36] Cody ML. Competition and Structure of Bird Communities. Princeton, NJ, USA: Princeton University Press, 1974. DOI: $10.2307 / 3734$.

[37] May RM. Some notes on estimating the competition matrix. Ecology, 1975, 56(3) : 737-741. DOI: 10.2307/1935511.

[38] Liu HP, Ye SW, Yang XF et al. Spatio-temporal characteristics of aquatic organism community and their relationship to environment in Niyang River, the branch of Yarlung Zangbo River, Tibet: 4. Zooplankton. J Lake Sci, 2016, 28(2) : 370-378. DOI : 10.18307/2016.0217. [刘海平, 叶少文, 杨雪峰等. 西藏尼洋河水生生物群落时空动态及与环境因 子关系: 4.浮游动物. 湖泊科学, 2016, 28(2): 370-378.]

[39] Ba S, Yang XL, Huang X et al. Phytoplankt on community structure and its relationship of water quality in spring and summer at the lower reach of the Lhasa Rriver. Plateau Science Research, 2017, 1(1):25-38. [巴桑, 杨欣兰, 黄香等. 拉萨河下游春、夏季浮游植物群落特征与水质评价. 高原科学研究, 2017, 1(1): 25-38.]

[40] Li SJ, Fan ZH, Ren YQ et al. Annual characteristics of phytoplankton communities at Yichang to chenglingji section in the middle reach of the Yangtze River. Resources and Environment in the Yangtze Basin, 2012, 21(S1) : 62-68. [李世健, 范 振华, 任玉芹等. 长江中游宜昌至城陵矶江段浮游植物群落结构的周年变化特征. 长江流域资源与环境, 2012, 21(S1) : 62-68.]

[41] Wang HW, Chen Y, Zhang XM et al. The algal community structure and seasonal variation in Taizi River catchment, Liaohe River basin. J Lake Sci, 2013, 25(6) : 936-942. DOI: 10.18307/2013.0618. [王宏伟, 陈荣, 张晓明等. 辽河太子 河流域藻类植物群落结构及其季节变化. 湖泊科学, 2013, 25(6) : 936-942.]

[42] Yang WH, Shen H, Zhou ML et al. Ecological characteristics of dominant phytoplankton community in Lake Nanhai( Baotou ) during freezing-thawing period. J Lake Sci, 2020, 32(2) : 450-461. DOI: 10.18307/2020.0214. [杨文焕, 申涵, 周明利等. 冻融期包头南海湖浮游植物群落及优势种生态特征. 湖泊科学, 2020, 32(2) : 450-461.]

[43] Zhu AM, Chen MX, Li SX. Evaluation of water ecological status of Chishui River in dry season based on phytoplankton. Environmental Science and Technology, 2020, 43(S1): 183-189. [朱爱民, 陈明秀, 李嗣新. 基于浮游植物的赤水河 枯水期水生态状况评价. 环境科学与技术, 2020, 43(S1) : 183-189.]

[44] Wang JG, Yu HX, Ma CX et al. Ecological factors and phytoplankton community structure in Xiquanyan Reservoir, Harbin, P.R.China. J Lake Sci, 2015, 27(4) : 667-678. DOI: 10.18307/2015.0415. [王建国, 于洪贤, 马成学等. 哈尔 滨西泉眼水库夏季浮游植物群落结构动态特征. 湖泊科学, 2015, 27(4) : 667-678.]

[45] Zhang RC, Zhao JC, Cao Z. Algae investigation and water quality evaluation in huaishahe river and huaijiuhe river of Beijing. Journal of Anhui Agricultural Sciences, 2007, 35(35) : 11593-11595. [张茹春, 赵建成, 曹珍. 北京怀沙河、怀九 河污染指示藻类水质评价. 安徽农业科学, 2007, 35(35): 11593-11595.]

[46] Li B, Feng J, Xie SL. Distribution and floristic characteristics of algae in the Gongbu Nature Reserve, Tibet. Acta Botanica Boreali-Occidentalia Sinica, 2012, 32(4) : 807-814. [李博, 冯佳, 谢树莲. 西藏工布自然保护区藻类植物区系及分 
布特点. 西北植物学报, 2012, 32(4): 807-814.]

[47] Pan H, Tang YH. Pollution indicator species and evaluation of water quality in Caohailake, Weining. Wetland Science, 2016, 14(2) : 230-234. [潘鸿, 唐宇宏. 威宁草海浮游植物污染指示种及水质评价. 湿地科学, 2016, 14(2): 230-234.]

[48 ] Wang JL, Liu DY, Gu BH et al. Environmental assessment of Lake Taiping (Anhui Province) based on a phytoplankton community analysis. J Lake Sci, 2014, 26(6) : 939-947. DOI : 10.18307/2014.0617. [王俊莉, 刘冬燕, 古滨河等. 基 于浮游植物群落的安徽太平湖水环境生态评价. 湖泊科学, 2014, 26(6) : 939-947.]

[49] Mi WM, Shi JQ, Yang YJ et al. Changes in epilithic algae community and its relationship with environmental factors in the meixi river, a tributary of the Three Gorges reservoir. Environmental Science, 2020, 41(4) : 1636-1647. DOI: 10.13227/ j.hjkx.201909253. [米文梅, 施军琼, 杨燕君等. 三峡库区支流梅溪河附石藻类群落变化及其与环境因子的关系. 环境科学, 2020, 41(4): 1636-1647.]

[50] Sun WX, Wu DJ, Pei HY et al. Phytoplankton community structure and environmental factors in a newly built reservoir, Shandong Province. J Lake Sci, 2019, 31(3) : 734-745. DOI: 10.18307/2019.0312. [孙文秀, 武道吉, 裴海燕等. 山 东某新建水库浮游藻类的群落结构特征及其环境驱动因子. 湖泊科学, 2019, 31(3) : 734-745.]

[51] Ma YH, Zeng Y, Ren LP et al. Community structure of phycophyta and evaluation of water quality in Sichuan section of Jialing River. Chinese Journal of Applied Ecology, 2012, 23(9) : 2573-2579. DOI: 10.13287/j.1001-9332.2012.0353. [马永红, 曾燏, 任丽萍等. 嘉陵江四川段藻类植物群落结构及水质评价. 应用生态学报, 2012, 23 (9): 2573-2579.]

[52] Wei JL, Cao PF, Hu WR et al. Seasonal succession of planktonic diatom community and its relationship with environmental factors in nansi lake. Research of Environmental Sciences, 2015, 28(8) : 1209-1218. [韦洁琳, 曹鹏飞, 胡文容等. 南四湖浮游硅藻季节性演替及其与环境因子的相关性. 环境科学研究, 2015, 28(8)：1209-1218.]

[53] Fan YW, Li J, Men XY et al. Preliminary description of diatom community and its relationship with water physicochemical variables in Qixinghe Wetland. Chinese Journal of Oceanology and Limnology, 2012, 30(3) : 379-387. DOI: 10.1007/ s00343-012-1108-9.

[54] Meng SL, Chen JC, Fan LM et al. Eco-characteristics of phytoplankton in Lake Wuli, Lake Taihu in 2007. J Lake Sci, 2009, 21 (6) : 845-854. DOI: 10.18307/2009.0615. [孟顺龙, 陈家长, 范立民等. 2007 年太湖五里湖浮游植物生态 学特征. 湖泊科学, 2009, 21(6): 845-854.]

[55] Wathne JA, Haug T, Lydersen C. Prey preference and niche overlap of ringed seals Phoca hispida and harp seals P. groenlandica in the Barents Sea. Marine Ecology Progress Series, 2000, 194: 233-239. DOI: 10.3354/meps194233.

[56] Yang WH, Shen H, Zhou ML et al. Seasonal variation analysis of the niche and interspecific association with respect to the dominant phytoplankton species in Nanhai Lake. China Environmental Science, 2020, 40(1) : 383-391. [杨文焕, 申涵, 周明利等. 包头南海湖浮游植物优势种生态位及种间联结性季节分析. 中国环境科学, 2020, 40(1): 383-391.]

[57] Xia T, Chen J, Cao FY et al. Niche analysis of phytoplankton in an urban river connected with the Yangtze River, Zhenjiang, China. Resources and Environment in the Yangtze Basin, 2014, 23 (3) : 344-350. DOI: 10. 11870/cjlyzyyhj201403006. [夏霆, 陈静, 曹方意等. 镇江通江城市河道浮游植物优势种群生态位分析. 长江流域资源与环境, $2014,23(3): 344-350$.]

[58] Pang CH, Fan X, Zhang F et al. The niches of dominant species in different resource dimensions in the lower reaches of Fenhe River, Shanxi Province of China. Chinese Journal of Ecology, 2015, 34(2) : 380-386. DOI: 10.13292/j.10004890.2015.0053. [庞春花, 范晓, 张峰等. 不同资源维度上汾河流域下游优势种的生态位. 生态学杂志, 2015, 34 (2) : 380-386.]

[59] Chen HL, He F, Basang et al. Preliminary study on water chemistry of Mitika Wetland, in Tibet. Plateau Science Research, 2020, 4(1) : 14-19. [陈虎林, 何峰, 巴桑等. 西藏麦地卡湿地水化学特征初探. 高原科学研究, 2020, 4 (1) : 14-19.] 